\title{
Perustoimeentulotuen siIrto KelaAn KASVATTI EDUSKUNNAN OIKEUSASIAMIEHELLE TEHTYJEN KANTELUIDEN MÄÄRÄÄ
}

\author{
Riikka Jackson: OTM, vanhempi oikeusasiamiehensibteeri, Eduskunnan oikeusasiamiehen kanslia \\ Paula Saikkonen: VTT, erikoisasiantuntija, Terveyden ja byvimvoinnin laitos
}

riikkea.jackson@eduskunta.fi;paula.saik.konen@thl.fi

Janus vol. 28 (2) 2020, 194-201

JOHDANTO

Perustoimeentulotuki siirtyi kunnista Kelan järjestämisvastuulle 1.1.2017. Uudistuksella tavoiteltiin säästöjä ja käytäntöjen sujuvuutta, kun Kelan resurssit, järjestelmä ja asiantuntemus hyödynnettäisiin toimeentulotuen myöntämisessä ja maksatuksessa (VTV 2020). Siirrossa ei merkittävästi muutettu toimeentulotuen sisältöä, rakennetta eikä tavoitteita, vaan uudistus koski ensisijaisesti toimeentulotuen hallinnointia (HE 358/2014). Erityisesti alkuvaiheessa siirto aiheutti vaikeuksia osalle asiakkaista, eikä kaikkia ongelmia saatu korjattua vielä vuoden 2017 aikana (esim. Blomgren \& Saikkonen 2018a; Blomgren \& Saikkonen 2018b). Tämä näkyi myös eduskunnan oikeusasiamiehelle tehtyjen kantelujen määrän kasvuna. Vuoden 2017 aikana Kelan menettelystä perustoimeentulotukihakemusten käsittelyssä tehtiin yhteensä 775 kantelua (vuonna 2016 kanteluita 114), joista saman vuoden aikana ratkaistiin 719. Noin puolet ratkaisuista johti oikeusasiamiehen toimenpiteisiin ${ }^{1}$; tässä keskitymme näihin kanteluihin. Kanteluiden määrän kasvua osittain selittää se, että siirron yhteydessä eduskunnan oikeusasiamies ja valtioneuvoston oikeuskansleri jäivät ainoiksi perustoimeentulotuen myöntämistä valvoviksi viranomaisiksi, sillä aiemmin kanteluja käsitelleillä aluehal- lintovirastoilla ei ole toimivaltaa valvoa Kelaa. Kuvaamme oikeusasiamiehelle tehtyjen kanteluiden ja niihin annettujen ratkaisujen perusteella ongelmia, joita perustoimeentulotuen siirrosta Kelaan aiheutui toimeentulotuen hakijoille. Laillisuusvalvonnan luonteesta johtuen siirron myönteiset vaikutukset eivät esiintyneet kanteluissa, eivätkä ne siten tule tässä huomioiduksi.

Perustoimeentulotuen siirto Kelaan toi valmisteluvaiheessa esille toimeentulotuen kokonaisuudistuksen tarpeen (StVM 33/2016 vp). Tämä on mainittu myös pääministeri Sanna Marinin hallituksen ohjelmassa $(2019,160)$. Asiakirjojen perusteella voidaan sanoa, etteivät esiin tulleet ongelmat olleet ennakoimattomia: sosiaali- ja terveysvaliokunta linjasi mietinnössään (StVM 54/2014 vp, 5), että valmis "toimintamalli, jolla asiakkaan saumaton ja kokonaisvaltainen palvelu Kelan ja kuntien välisellä yhteistyöllä hoidetaan" on välttämätön riittävän asiakaspalvelun varmistamiseksi. Tämän mallin puuttumista pahoiteltiin jälkimmäisessä valiokunnan mietinnössä vain paria kuukautta ennen siirron toteutumista. Kelan ja kuntien yhteistyön tärkeyttä uudistuksessa painotti valiokuntalausunnossaan myös eduskunnan oikeusasiamiehen kanslia (Dnro 521/5/15). 
Valtiontalouden tarkastusvirasto (2020) on selvityksessään tarkastellut toimeenpanon vaikutusten arvioinnin merkitystä lainvalmistelussa. Tässä aineistona hyödynnetyt kantelut ja niiden ratkaisut tuovat puolestaan esiin toimeentulotuen hakijoiden kokemia ongelmia. Toimeentulotukea haetaan vaihtelevissa, toisinaan hyvin hankalissa elämäntilanteissa. Toimeentulotuki on luonteeltaan viimesijainen tuki, joka on tarkoitettu tilanteeseen, jossa henkilön tai perheen tulot eivät riitä välttämättömiin arjen menoihin. Taloudellisen tuen tarpeen lisäksi asiakkaalla ja hänen perheellään saattaa olla myös muita sosiaalihuoltoon liittyviä tarpeita. Toimeentulotuen hakijoiden yhteiskunnallinen asema on usein heikko.Vaikka toimeentulotukea ennen uudistusta haettiin toisinaan vain taloudellisten resurssien riittämättömyyden vuoksi, oli toimeentulotuki monelle myös enemmän kuin syyperustaisen sosiaaliturvan puutteita paikkaava etuuden kaltainen tuki (Saikku \& Kuivalainen 2013; Blomgren ym. 2016).

Toimeentulotuen siirto Kelaan on ollut esillä miltei sosiaalihuoltolain synnystä lähtien. Siirtoa myös kokeiltiin eri tavoin 1990-luvulla ja vielä 2000-luvullakin. (Kangas ym. 2011.) Lainsäädännössä toimeentulotuki on säilynyt osana sosiaalihuoltoa ja siten yhteydessä sosiaalityöhön (L 1412/1997; StVM 53/2014 vp). Sidos sai alkunsa asiakaslähtöisyyttä korostaneessa vuoden 1984 sosiaalihuoltolaissa, jonka tavoitteena oli edistää asiakkaan omatoimisuutta sekä turvata yksilölähtöinen ja tarpeenmukainen tuki ilman asiakkaan leimaamista (vrt. köyhäinhoito tai huoltoapu). Osana sosiaalihuoltolakia toimeentulotuesta säädettiin 1.3.1998 saakka, jolloin toimeentulotukilaki astui voimaan.

\section{VUODEN 2017 ALUSSA PALJON VIIVÄSTYSTÄ TUEN MYÖNTÄMISESSÄ}

Päätös perustoimeentulotuen siirrosta Kelaan tehtiin Kataisen hallituksen julkisen talouden suunnitelmassa (Valtioneuvoston selonteko 2014). Uudistus toteutettiin Sipilän hallituksen aikana. Siirron edellyttämä lainsäädäntö valmistui runsas kuukausi ennen siirron toteutumista (HE 217/2016 vp). Näin kunnille ja Kelalle jäi varsin vähän aikaa valmistautua toteutukseen, eikä sujuvia käytäntöjä hakemusten käsittelylle ehtinyt syntyä. Vuoden ensimmäisellä neljänneksellä apulaisoikeusasiamies vastaanotti yli 400 kantelua, joissa arvosteltiin ensisijaisesti perustoimeentulotukihakemusten käsittelyn viivästymistä. Viivästykset perustoimeentulotukihakemusten käsittelyssä olivat kantelujen perusteella merkittäviä. Hakemuksen käsittely saattoi kestää laissa toimeentulotuesta (1412/1997) säädetyn seitsemän arkipäivän sijaan useita viikkoja tai jopa kuukauden. Alkuvuonna 2017 apulaisoikeusasiamies antoi Kelalle yhteensä 36 erillistä huomautusta toimeentulotukihakemusten käsittelyn viivästymisistä.

Kanteluratkaisuissaan apulaisoikeusasiamies piti Kelan menettelyä toimeentulotuen käsittelyn ruuhkautumisessa erityisen moitittavana: toimeentulotu$\mathrm{ki}$ on viimesijainen taloudellinen tuki, joka on tarkoitettu tilanteeseen, jossa henkilön tai perheen tulot eivät riitä välttämättömiin jokapäiväisiin menoihin. Kelan mukaan viivästykset johtuivat hakemusten käsittelyprosessin 
ongelmista, lisääntyneestä hakemusmäärästä ja järjestelmäteknisten syiden aiheuttamasta ruuhkasta. Viivästyksiä perusteltiin myös liian vähäisellä henkilöstömäärällä. Tältä osin apulaisoikeusasiamies totesi, että Kelan tuli osoittaa voimavaroja lakisääteisiin tehtäviinsä ja huolehtia siitä, että sillä on käytössään riittävästi ammattitaitoista henkilökuntaa. Henkilökunnan vähäisyys tai puutteet sen osaamisessa eivät oikeuttaneet viivästyksiin toimeentulotukihakemusten käsittelyssä. (Esim. EOAK/649/2017.)

Kela ryhtyi saamiensa huomautusten johdosta toimenpiteisiin ruuhkan purkamiseksi ja rekrytoi lisää toimihenkilöitä. Kelan toimenpiteet eivät kuitenkaan vielä kevään 2017 aikana olleet riittäviä, sillä apulaisoikeusasiamiehelle toimitettiin edelleen kanteluita, joiden mukaan hakemusten käsittelyssä oli ongelmia. Huhtikuun loppupuolella vuonna 2017 Kela ilmoitti pystyvänsä jatkossa käsittelemään hakemukset laissa säädetyssä seitsemän arkipäivän määräajassa. Pahimman ruuhkan helpottumisen ja Kelan toimenpiteiden jälkeen apulaisoikeusasiamies tyytyi ratkaisuissaan $(221 \mathrm{kpl})$ kiinnittämään Kelan huomiota lainmukaiseen menettelyyn toimeentulotukihakemusten käsittelyssä.

Apulaisoikeusasiamies (EOAK/1301/ 2017) esitti Kelalle, että se suorittaisi hyvitystä niille asiakkaille, joille oli aiheutunut taloudellista vahinkoa, haittaa ja vaivannäköä Kelan lainvastaisesta menettelystä. Kela ilmoitti maksavansa hyvitysmaksua niille myönteisen toimeentulotukipäätöksen saaneille asiakkaille, joiden hakemuksen ratkaiseminen oli viivästynyt lainmukaisesta määräajasta. Hyvityksen määrä oli 25150 euroa viivästyksen pituudesta riippuen. Kela ilmoitti tiedotteessaan huhtikuussa (24.4.2017) maksavansa erikseen viivästys- ja muistutuskulut, jotka olivat aiheutuneet asiakkaan laskun käsittelyn myöhästymisestä, ja että asiakkaat voisivat myös hakea vahingonkorvausta Kelasta. Kelan ilmoitettua hyvitysten maksamisesta apulaisoikeusasiamiehelle toimitettiin useita kanteluita, joissa arvosteltiin sitä, ettei asiakkaille kaikissa tapauksissa maksettukaan hyvitystä. Useimmiten kysymys oli ajallaan myönteisen toimeentulotukipäätöksen saaneen asiakkaan laskujen maksamisen myöhästymisistä. Kela oli kuitenkin linjannut, että hyvitystä maksetaan pelkästään varsinaisen toimeentulotukihakemuksen käsittelyn viivästymisestä.

\section{Asiakaspalvelu vaikeUksissa kUN UUDET KÄYTÄNNÖT MUOTOUTUVAT}

Hakemusten käsittelyn viivästymisen lisäksi apulaisoikeusasiamiehelle toimitetuissa kanteluissa tuotiin esille puhelinpalvelun ruuhkautumista, kiireellisen toimeentulotuen ongelmia, arvosteltiin Kelan omia sisäisiä toimeentulotukiohjeita, tulojen ja menojen arviointia ja yhteistyötä kuntien kanssa. Käsittelemme näitä teemoja seuraavaksi. Tämän jälkeen kerromme siitä erityisestä ongelmasta, että toimeentulotukea jätettiin myöntämättä lääkkeisiin ja muihin terveydenhuoltomenoihin.

\section{Ruuhkainen ja maksullinen puhelinpalvelu}

Hakemusten käsittelyn viivästymisestä seurasi Kelan puhelinpalvelun ruuhkautuminen alkuvuonna 2017. Esimer- 
kiksi toimeentulotuen puhelinpalvelun jonotusajat olivat maaliskuussa 2017 keskimäärin 23 minuuttia, mistä ajasta asiakas joutui maksamaan puhelinoperaattorinsa määräämän minuuttimaksun. Kantelujen mukaan pahimmillaan jonottaminen saattoi kestää yli 45 minuuttia. Kelan palvelunumero ei kuulunut operaattorien tarjoamiin puhepaketteihin, jolloin Kelaan soittamisesta veloitettiin puhepaketin kuukausimaksun lisäksi erillinen maksu. Apulaisoikeusasiamies katsoi puhelinpalveluja koskeviin kanteluihin antamissaan ratkaisuissa, että pitkät jonotusajat aiheuttivat toimeentulotukiasiakkaille heidän taloudelliseen tilanteeseensa nähden kohtuuttomia kustannuksia. Kela ryhtyi asiassa korjaaviin toimenpiteisiin ja tilanne puhelinpalvelun osalta parantui toukokuussa 2017, jolloin keskimääräinen jonotusaika laski 4,5 minuuttiin. (Esim. EOAK/2879/2017.)

Kiireellisen toimeentulotuen myöntämisessä ongelmia

Kiireellinen toimeentulotukea koskeva hakemus on käsiteltävä siten, että päätös voidaan tehdä käytettävissä olevien tietojen perusteella samana tai viimeistään seuraavana arkipäivänä hakemuksen saapumisesta (L 1412/1997). Apulaisoikeusasiamies kiinnitti edellä mainitussa puhelinpalveluita koskevan ratkaisunsa yhteydessä huomiotaan Kelan käytäntöön, jonka mukaan kiireellisen toimeentulotukihakemuksen tekeminen saattoi tapahtua vain asioimalla henkilökohtaisesti toimipisteessä tai soittamalla puhelinpalveluun. Kiireellistä toimeentulotukea ei siis voinut hakea sähköisellä lomakkeella. Kelan mukaan kiireellisinä pidettäviä toimeentulotukihakemuksia ei ollut teknisistä syistä mahdollista tunnistaa sähköisen asiointijärjestelmän hakemusjonoista. Tästä seurasi, että mikäli Kelan toimipistettä ei ollut kohtuullisen matkan päässä, se ei ollut auki tai se oli ruuhkautunut, jäi asiakkaan ainoaksi vaihtoehdoksi asioida puhelimitse saadakseen toimeentulotukihakemuksensa kiireellisesti käsiteltäväksi. Tällöin puhelinpalvelun tosiasiallisella saatavuudella oli erityinen merkitys kiireellistä toimeentulotukea tarvitsevalle asiakkaalle. Apulaisoikeusasiamies katsoi, että Kelan tulisi kehittää puhelinpalveluaan siten, että kiireellisiin yhteydenottoihin pystyttäisiin kaikissa tilanteissa vastaamaan oikea-aikaisesti. (EOAK/2879/2017.)

\section{Puntteita Kelan päätöksenteossa}

Lukuisissa apulaisoikeusasiamiehelle toimitetuissa kanteluissa esitettiin, että Kela ei käsitellyt toimeentulotukihakemuksia kaikilta osin, päätöksissä oli puutteellisia tai virheellisesti laadittuja laskelmia tuloista ja menoista tai asiakkaat joutuivat toistuvasti toimittamaan Kelaan samoja selvityksiä, jotka he olivat jo kertaalleen toimittaneet. Virheet päätöksissä ja hakemusten huolimaton käsittely johtivat päätösten oikaisuvaatimuksiin ja Kelan toistuviin päätösten itseoikaisuihin viivästyttäen entisestään hakemusten käsittelyä. Apulaisoikeusasiamies kiinnitti useissa ratkaisuissaan Kelan huomiota hyvän hallinnon vaatimuksiin ja päätöksentekovelvollisuuden toteuttamiseen. (Esim. EOAK/1204/2017.)

\section{Kuntien ja Kelan välinen yhteistyö}

Vuonna 2017 tehdyt kantelut kertovat, ettei Kela ottanut riittävällä tavalla huomioon yhteistyövelvoitteita 
kuntien kanssa. Kuntien ja Kelan väliseen yhteistyöhön liittyvät ongelmat näyttivät kantelujen perusteella realisoituvan ensisijaisesti kiireellisten toimeentulotukihakemusten yhteydessä ja etenkin silloin, kun Kelan toimipisteet olivat kiinni. Lisäksi yhteistyöhön liittyviä konkreettisia ongelmia oli muun muassa asumismenojen huomioimisessa, velvollisuudessa ilmoittautua työttömäksi työnhakijaksi, perusosan alentamisessa, monialaisten suunnitelmien laatimisessa ja sosiaalipalveluista perittävien maksujen alentamisessa. (Esim. EOAK/5044/2017, EOAK/6708/2017.)

Apulaisoikeusasiamiehelle osoitetuissa kanteluissa tuli esille sosiaalihuollon asiakkaiden kokemus ohjaamisesta edestakaisin Kelan ja kunnan sosiaaliviranomaisten välillä. Kunnat olivat saattaneet kieltäytyä käsittelemästä asiakkaan hakemusta ja ohjanneet hänet Kelaan samalla, kun Kela oli arvioinut kyseisen asian kuuluvan kunnan ratkaistavaksi. Joistakin kanteluista kävi ilmi, että kunta oli päätynyt myöntämään täydentävää toimeentulotukea sellaisiin menoihin, jotka olisivat kuuluneet Kelan perustoimeentulotukeen. Ratkaisussaan apulaisoikeusasiamies totesi (EOAK/2225/2017), että vaikka perustoimeentulotuen myöntäminen on Kelan tehtävä, on myös kunnalla velvollisuus arvioida kiireellisen tuen myöntämistä, jos välttämätöntä kiireellistä apua tai tukea ei ole tosiasiassa muutoin järjestettävissä. Tämä kattaa tilanteet, joissa Kelan toimipaikka on auki, mutta Kela ei käytännössä pysty käsittelemään hakemuksia ja tekemään päätöksiä laissa säädetyssä ehdottomassa määräajassa. Kiireellisissä tilanteissa perustoimeentulotukea myöntävän Kelan ja täydentävää ja ehkäisevää toimeentulotukea myöntävän kunnan viranomaisten välisen yhteistyön merkitys korostuu.

Kelan on hakijan pyynnöstä toimitettava hakemus viipymättä asiassa toimivaltaiseen kuntaan tehtyään hakemuksen perusteella päätöksen perustoimeentulotuesta, jos hakija on esittänyt hakemuksessaan muita kuin perustoimeentulotukeen kuuluvia menoja (L 1412/1997, 14 d \$). Kelan on lisäksi hakemusta käsitellessään arvioitava, onko asiakkaalla kiireellinen täydentävän tai ehkäisevän tuen tarve. Jos tuen tarve arvioidaan kiireelliseksi, Kelan on käsiteltävä hakemus myös perustoimeentulotuen osalta kiireellisenä.

Se, miten toimeentulotukihakemukset ja päätökset liikkuvat Kelan ja kunnan välillä, ei ole yhdentekevää. Esimerkkinä mainittakoon kantelu EOAK/1031/20172, jossa kysymys oli lämmitysöljyn kustannuksista. Kela ei ollut myöntänyt asiakkaalle toimeentulotukea öljyyn, vaan se oli kehottanut asiakasta hakemaan ehkäisevää toimeentulotukea kunnan sosiaalitoimelta siirtäen hakemuksen kuntaan. Apulaisoikeusasiamies piti Kelan menettelyä asiassa toimeentulotukilain vastaisena, koska kyseessä oli meno, joka kuului huomioitavaksi perustoimeentulotuessa.Tämän lisäksi Kela siirsi hakemuksen sosiaalitoimen käsiteltäväksi ilman, että se olisi yhteistyössä asianomaisen kunnan kanssa selvittänyt, onko asiakkaan tuen tarve kiireellinen. Apulaisoikeusasiamies katsoi ratkaisussaan, että arvio asiakkaan tilanteesta olisi tullut tehdä asian luonteen vuoksi välittömästi. Asian kiireellisyys olisi pitänyt Kelassa ymmärtää jo asiakkaan hakemuksista ja 
lukuisista yhteydenotoista Kelaan. Iäkäs yksin asuva asiakas oli asiassa saadun selvityksen mukaan ilman lämmitysöljyä ainakin helmikuusta maaliskuun loppuun asti, minä aikana hänen asuntonsa lämpötila oli ollut vain +10 astetta.

\section{JATKUVANA HAASTEENA PERUSTOIMEENTULOTUKEEN KUULUVAT TERVEYDENHUOLTOMENOT}

Kanteluissa arvosteltiin Kelaa siitä, ettei se myöntänyt toimeentulotukea asiakasta hoitavan lääkärin määräämiin lääkkeisiin tai muihin terveydenhuoltomenoihin toimeentulotukilain edellyttämällä tavalla. Apulaisoikeusasiamies kiinnitti lääkemenoihin liittyvissä ratkaisuissaan Kelan huomiota siihen, ettei toimeentulotukilaki rajaa, mihin lääkkeisiin tukea voidaan myöntää. Lääkkeeltä ei myöskään edellytetä sairausvakuutuskorvattavuutta, vaan kysymys on siitä, ovatko asiakkaan esittämät terveydenhuoltomenot tarpeellisia hakijan sairauden- tai terveydenhoidossa toimeentulotukilaissa tarkoitetulla tavalla. (EOAK/2112/2017.)

Ratkaisussaan (mt.) apulaisoikeusasiamies katsoi, että toimeentulotuen hakijalta voidaan edellyttää, että hän toimittaa tarvittaessa selvityksen terveydenhuoltomenojensa tarpeellisuudesta. Tällainen selvitys on esimerkiksi lääkemääräys tai hoitavan lääkärin antama lausunto. Kelan tulee arvioida yksilöllisesti, millä tavoin ja missä laajuudessa asiakkaalta pyydetään lisäselvitystä terveydenhuoltomenoista. Kelan oman asiantuntijalääkärin lausunnolla ei voi olla yksin ratkaisevaa merkitystä päätöksenteossa. Apulaisoikeusasiamies kiinnitti huomionsa myös siihen, että Kela oli toimeentulotukea myöntäessään edellyttänyt asiakkaiden tekevän erillisen hakemuksen niin sanotun rajatun maksusitoumuksen saamiseksi tiettyihin Kelan määrittelemiin lääkkeisiin. Toimeentulotukilaissa ei kuitenkaan ole säännöksiä erilaisista maksusitoumuksista eikä maksusitoumuksiin liittyvästä erityisestä hakumenettelystä. Yksi toimeentulotukihakemus, jossa menot esitetään, on apulaisoikeusasiamiehen mukaan riittävä. (EOAK/2112/2017.)

Syksyllä 2017 Kela muutti lääkemenojen hyväksymiseen liittyvää käytäntöään ja julkaisi internetissä esityksen, jossa muutoksia esitellään. Apulaisoikeusasiamiehelle osoitettujen kantelujen perusteella Kela alkoi tässä vaiheessa vaatia joiltakin tiettyjä lääkkeitä käyttäviltä asiakkailta laajamittaisia selvityksiä lääkkeen välttämättömyydestä, diagnooseista ja muista asiakkaan terveydenhuoltoon liittyvistä asioista. Kantelunalaisissa tilanteissa kysymys oli muun muassa kilpirauhaslääkkeistä, lääkekannabiksesta, joistakin vahvoista kipulääkkeistä ja ADHD-lääkkeistä, joita asiakasta hoitanut lääkäri oli määrännyt asiakkaalle. Näihin kanteluihin apulaisoikeusasiamies teki ratkaisunsa vuonna 2018 (EOAK/6468/2017). Siinä todettiin, ettei Kela voi kategorisesti ilman laissa säädettyä perustetta rajata tiettyjä lääkeaineita tai -valmisteita toimeentulotuen ulkopuolelle. Apulaisoikeusasiamies piti tällaista Kelan ohjetta itsessään syrjivänä. Ratkaisussaan apulaisoikeusasiamies totesi, että terveydenhuoltomenot kuuluvat perustoimeentulotukeen ja ovat osa ihmisarvoisen elämän kannalta välttämätöntä toimeentuloa. Kelan omaksuma tulkinta saattoi vaarantaa toimeentulotukiasiakkaan tar- 
vitseman hoidon jatkuvuuden ja hänen oikeutensa perustuslaissa taattuihin riittäviin ja tarpeen mukaisiin terveyspalveluihin. (EOAK/6468/2017.)

\section{VIIMESIJAISESSA TURVASSA TARVITAAN YKSILÖLLISTÄ HARKINTAA}

Edellä esitettiin ne pääteemat, jotka esiintyivät vuonna 2017 perustoimeentulotuen siirtämisestä Kelaan oikeusasiamiehelle tehdyissä kanteluissa ja niiden ratkaisuissa. Suurin osa kanteluista piti sisällään enemmän kuin yhden teeman. Kanteluiden määrä oli heti tammikuussa korkea. Julkisuuden kasvaessa kanteluiden määrä vielä lisääntyi. Pidämme kuitenkin epätodennäköisenä, että kaikki mielestään kaltoin kohdellut toimeentulotuen hakijat olisivat kirjelmöineet oikeusasiamiehelle, vaik$\mathrm{ka}$ viimesijaisen turvan toimeenpanossa tapahtuneiden virheiden seuraukset voivat olla kohtalokkaita (esim. häätö, turvautuminen pikavippiin, luopuminen lääkityksestä). Kela korjasi virheitä ja ongelmia kanteluratkaisujen myötä. Kanteluissa esiintyivät ne samat teemat, mitä kuntien sosiaalihuollossa on havaittu (Blomgren \& Saikkonen 2018a;2018b). Omia tutkimusaiheitaan olisivat, onko toimeentulotuen hakijoilla riittävästi mahdollisuuksia suhteessa heidän voimavaroihin puuttua Kelan toimintaan silloin, kun he kokevat tulleensa väärin kohdelluiksi tai miten isoa osaa toimeentulotuen hakijoista tässä mainitut ongelmat koskivat ja minkälaisella syvyydellä.

Osa uudistuksen aiheuttamista ongelmista osattiin ennakoida sosiaali- ja terveysvaliokunnassa. Jälkimmäisen valiokuntakuulemisen jälkeen ei enää ollut epäselvyyttä siitä, että Kelan asiakastietojärjestelmän toimivuudessa oli hyvin paljon toivomisen varaa eikä Kelan ja kuntien välille ollut ehtinyt syntyä valiokunnan toivomia toimintamalleja (StVM 33/2016 vp). Osa ongelmista, kuten merkittävät viivästykset hakemusten käsittelyssä ja puhelinpalvelun ruuhkautuminen, korjaantuivat, joskin varsin verkkaisesti, Kelan ryhdyttyä toimenpiteisiin laillisuusvalvojan päätöksen saatuaan. Vaikka Kela pääsääntöisesti ryhtyi korjaaviin toimenpiteisiin, on osa ongelmista yhä ratkaisematta. Esimerkiksi tietyt terveydenhuoltomenot rajataan edelleen kategorisesti toimeentulotuen ulkopuolelle.

Eduskunnan oikeusasiamies on instituutiona profiloitunut perus- ja ihmisoikeuksien turvaajana (Nieminen 2018). Toimeentulotukikysymykset ovat olleet oikeusasiamiehen selvittelyssä ennen siirtoakin, jolloin on kiinnitetty huomiota muun muassa siihen, että kuntien ohjeet ovat eronneet suuresti toisistaan (HE 358/2014 vp, 13). Ohjeita on myös noudatettu liian yksityiskohtaisesti eikä yksilölliselle tarveharkinnalle ole jätetty riittävästi tilaa. Kantelujen perusteella yhtenä vakavimmista ongelmista olivat puutteet toimeentulotukihakemusten $\mathrm{yk}$ silöllisessä harkinnassa myös siirron jälkeen. Perustoimeentulotuen ollessa sosiaalihuoltoon kuuluva viimesijainen taloudellinen tuki, ei toimeentulotukihakemusta voida ratkaista pelkästään matemaattisen laskelman ja kaavamaisesti Kelan soveltamisohjeiden mukaisesti. Päätöksenteossa on tehtävä yksilöllistä harkintaa ja huomioitava hakijan sekä muiden päätökseen osallisten elämäntilanne. Tarkastelumme perusteella ainakaan ensimmäisen toimintavuoden 
aikana siirron jälkeen Kela ei päätöksenteossaan kyennyt riittävästi arvioimaan hakijoiden yksilöllisiä olosuhteita ja siten huolehtimaan riittävästä tuesta heikoissa asemassa oleville.

\section{VIITTEET}

1 Oikeusasiamiehen pääasiassa käyttämiä toimenpiteitä ovat esitys, moittiva käsitys ja ohjaava käsitys. Lisäksi on olemassa syyte, mutta sitä käytetään harvoin. Oikeusasiamies voi esittää myös hyvitystä.

2 Ratkaisua ei ole julkaistu eduskunnan oikeusasiamiehen internetsivulla.

\section{Kirjallisuus}

Blomgren, Sanna \& Karjalainen, Jouko \& Karjalainen, Pekka \& Kivipelto, Minna \& Saikkonen, Paula \& Saikku, Peppi (2016) Sosiaalityö, palvelut ja etuudet muutoksessa. Raportteja 4. Helsinki:THL.

Blomgren, Sanna \& Saikkonen, Paula (2018a) Toimeentulotukiuudistus haastoi kuntien ja Kelan yhteistyön: kuntakyselyn tuloksia. Tutkimuksesta tiiviisti 7. Helsinki:THL.

Blomgren, Sanna \& Saikkonen, Paula (2018b) Viimesijaisen turvan palveluissa vielä parannettavaa: toimeentulotukiuudistuksen kuntakyselyn tuloksia. Tutkimuksesta tiiviisti 12 . Helsinki:THL.

EOAK/649/2017. Kelalle huomautus toimeentulotuen käsittelyn viivästymisestä.

EOAK/1031/2017. Apulaisoikeusasiamieheltä hyvitysesitys Kelalle.

EOAK/1204/2017. Kelan menettely toimeentulotukiasiassa.

EOAK/2112/2017. Millaisiin terveydenhuoltomenoihin voidaan myöntää toimeentulotukea.

EOAK/2225/2017. Kiireellisen toimeentulon myöntämistä koskeva ohjeistus

EOAK/2879/2017. Kelan puhelinpalvelut ruuhkautuivat pahasti.

EOAK/5044/2017. Laskennallisen tulon huomioiminen toimeentulotukilaskelmassa.

EOAK/6468/2017. Kelan muutokset toimeentulotukeen vaaransivat lääkehoidon jatkuvuuden ja terveyspalveluiden yhdenvertaisen saavutettavuuden.

EOAK/6708/2017. Asiakasmaksujen alentaminen ja pääöksenteko toimeentulotukiasiassa.

HE 358/2014 vp. Hallituksen esitys eduskunnalle laeiksi toimeentulotuesta annetun lain ja kunnan peruspalvelujen valtionosuudesta annetun lain muuttamisesta.

HE 217/2016 vp. Hallituksen esitys eduskunnalle laeiksi toimeentulotuesta annetun lain ja toimeentulotuesta annetun lain muuttamisesta annetun lain sekä eräiden niihin liittyvien lakien muuttamisesta.

Kangas, Olli \& Niemelä, Mikko \& Varjonen, Sampo (2011) Toimeentulotuen Kela-siirron kehykset politiikan asialistoilla ja kansalaismielipide. Teoksessa Mikko Niemelä \& Juho Saari (toim.) Politiikan polut ja hyvinvointivaltion muutos. Helsinki: Kelan tutkimusosasto, 144-177.

Kela (2017) Eduskunnan apulaisoikeusasiamiehenpäätös (EOAK/1301/2017) ja Kansaneläkelaitoksen (Kela) selvitys toimenpiteistä. Dnro 94/030/2017.

L 1412/1997. Laki toimeentulotuesta.

Nieminen, Liisa (2018) Eduskunnan oikeusasiamies. "Pienen ihmisen" asialla - joustavuutta vai hampaattomuutta näkökulmasta riippuen? Lakimies 116 (2), 143-176.

Pääministeri Sannan Marinin hallituksen ohjelma: Osallistava ja osaava Suomi sosiaalisesti, taloudellisesti ja ekologisesti kestävä yhteiskunta (2019). http://urn.fi/ URN:ISBN:978-952-287-808-3 Luettu 27.12.2019.

Saikku, Peppi \& Kuivalainen, Susan (2013) Toimeentulotukityö kunnissa - organisointi, työnjako ja kokemukset. Teoksessa Susan Kuivalainen (toim.) Toimeentulotuki 2010-luvulla. Raportteja 9. Helsinki: THL, 115-149.

StVM 54/2014 vp.Valiokunnan mietintö.

StVM 33/2016 vp.Valiokunnan mietintö.

Valtioneuvoston selonteko julkisen talouden suunnitelmasta vuosille 2015-2018.Valtioneuvoston kanslia, 2014. https://valtioneuvosto.fi/rakenneuudistus/julkisen-talouden-suunnitelma Luettu 20.11.2018.

Valtiontalouden tarkastusvirasto (2020) Perustoimeentulotuen siirto Kelalle: Toimeenpanon vaikutusten arvioinnin merkitys lainvalmistelussa. Tarkastuskertomukset 1. Helsinki:VTV. 